\title{
CO-FERMENTATION OF CARROTS, GRAIN RESIDUES AND POTATO CHIPS
}

\author{
Vilis Dubrovskis, Imants Plume, Indulis Straume \\ Latvia University of Life Sciences and Technologies, Latvia \\ vilisd@inbox.lv,imants.plume@inbox.lv, indulis.straume@1lu.lv
}

\begin{abstract}
Different raw organic materials can be used for production of methane in the anaerobic fermentation process. Every kind of biomass has the specific methane production potential. In practice, different biomasses are utilised in the biogas plant at the same time often, so enabling co-fermentation at different proportions. The purpose of this study was to ascertain how the co-fermentation of various biomasses affects the methane yield compared to methane release from the same biomass during its mono-fermentation. Different factors may influence the methane yield, and most important are carbon: nitrogen $(\mathrm{C}: \mathrm{N})$ ratio, presence of easy degradable carbohydrates, trace elements and other substances needed to provide optimal microbial activity. Investigations were provided in 16 bioreactors with volume 0.751 operating in batch mode at the temperature $38^{\circ} \mathrm{C}$. Equal amounts of the carrots, grain drying residue, potato chips and inoculums were processed in 3 different groups of bioreactors to observe methane production from individual biomass, mixed with inoculums, in the monofermentation process. The same biomasses, in proportion 1:1:1 by weight, and inoculums were mixed together and co-fermented in the fourth group of bioreactors. 2 bioreactors were filled with inoculums only for control. It was found that average specific methane production per gram of dry organic matter in the co-fermentation process was higher compared to average specific methane production obtained from the same biomasses (carrots and grain residues) in the mono-fermentation process, when each biomass was fermented individually.
\end{abstract}

Keywords: methane, anaerobic fermentation, carrots, grain drying residue, potato chips.

\section{Introduction}

With the exception of the last 200 years in the history of modern mankind, almost all our energy resources and materials were based on biomass. Wood was for centuries the primary resource, and specifically for energy purposes. Today, depletion of fossil resources and the increasing climate change have put biomass back in its role as one of our indispensable resources. Annually terrestrial plants produce more than 130 billion tons of dry matter, corresponding to 5 times of the current global energy consumption [1].

Biomass is a dispersed energy carrier that is concentrated before use. Consequently, biomass and bioenergy are inevitably linked to the use of land, which is the factor ultimately limiting the use of biomass. Biomass is a complex, renewable, but also limited resource. Both prices and demand for biomass are going up. The biomass composition is highly complex, it consists of several types of components, which can be developed into many types of products [2].

Today's economy and technologies largely depend upon energy resources that are renewable as well as eco-friendly. Biogas is an environment friendly, economic and alternative means to substitute fossil fuel [3]. Biogas has many advantages as a replacement for petrol and diesel. Biogas gives the smallest emissions of carbon dioxide and particulate matter of all vehicle fuels containing hydrocarbons on the market today. The methane molecule is the simplest of all hydrocarbons, which means that the exhaust produced by combustion is very clean. Emissions of carbon monoxide, hydrocarbons, sulphur compounds, nitrogen oxides, heavy metals and particulate matter are negligible. A gas engine is quieter compared to a diesel engine, which means a better workplace environment for professional drivers. Methane is a safer fuel than petrol or diesel, since gas is not poisonous and is lighter than air. If a leak should occur, methane would quickly rise up through the surrounding air.

Different raw organic materials can be used for production of methane in the anaerobic fermentation process [4]. Every kind of biomass has the specific methane production potential. In practice, different biomasses are utilised in a biogas plant at the same time often, so enabling cofermentation at different proportions. Commonly used substrates for biogas production include industrial waste, agricultural wastes, dairy and pig-breeding waste, e.g. fodder residues and manure, and energy crops, e.g. corn and grasses. However, some substrates can be degraded very slowly as the molecular structure of biomass is poorly accessible to microorganisms and their enzymes [5].

Co-fermentation is simultaneous digestion of a homogenous mixture of two or more co-substrates. Mixing of different substrates allows some flexibility in feedstock supply, allowing to compensate the 
seasonal mass fluctuations of wastes. Underloading or overloading of digesters can be avoided and the digestion process can be maintained at a constant rate.

Researchers show the positive effect of co-fermentation [6-8]. The following co-substrates were consistently used: corn silage, fresh grass, kitchen waste and grass silage. On the basis of the obtained results corn silage seems to be the most suitable co-substrate: its adding to the manure almost doubled the biogas production [9].In the same experiment, the kitchen waste addition led to an increase of the methane volume in the produced biogas, but only by less than $2 \%$.A similar experiment with cofermentation of manure with kitchen waste was done in laboratory conditions at the Institute for Biotechnology in Braunschweig [10], when kitchen waste was consequently added to the manure in proportion of 30,50 and $70 \%$.

In these experiments, the methane volume was significantly increased to $17 \%$ due to the kitchen waste addition to the manure and even increased to $50 \%$ due to prolongation of the substrate retention time in a digester up to 65 days in comparison with the experiments with pure manure fermentation. Organic wastes and by-products for co-digestion with their approximate biogas yields in $\mathrm{m} 3$ per ton organic solids are given by Braun [11]. Unfortunately, these data have large limitations and as such are not possible to be used for precise calculations, which are needed for biogas plant operators.

The aim of this study was to evaluate the biogas and methane production from potato chips, carrots and grain residues and to justify, whether the addition of these biomass mixtures in cofermentation can cause any positive effect.

\section{Materials and methods}

Dry matter and organic dry matter content in biomass was analysed before investigation for calculation of organic load rates. Total solid, ash and dry organic matter (DOM) contents of biomass were determined by known methods [12]. All substrates were carefully mixed together and filled in bioreactors before anaerobic fermentation (AF). Filled bioreactors were sealed and gas bags were connected using plastic pipes. All 16 bioreactors were placed into a heated camera at the same time before starting of anaerobic digestion.

Gases volume released from each bioreactor into the gas bag was measured using a flow meter (Ritter drum-type gas meter) with accuracy 0.0251 . The contents of oxygen, methane, carbon dioxide, and hydrogen sulphide in biogas were measured using a gas analyser (GA 2000) with accuracy $\pm 2 \%$. $\mathrm{pH}$ value measurements were provided before and after the AF process, using a $\mathrm{pH}$ meter (PP-50 model). Scales KFB $16 \mathrm{KO} 2$ (accuracy $\pm 0.2 \mathrm{~g}$ ) was used for weight measurements of inoculums and for total substrates before and after the AF process. Scales Shimazu (accuracy $\pm 0.001 \mathrm{~g}$ ) were used for measurements of weight of the added biomass samples, total solids, ashes and dry organic matter.

Batch mode anaerobic fermentation (AF) process was provided at temperature $38 \pm 0.5^{\circ} \mathrm{C}$ until gas production practically ceases. After the AF process was finished, every digestate was weighted and total solids, ashes and dry organic matter data were obtained. Experimental data were processed using Excel program and known statistical methods.

\section{Results and discussion}

Results of analyses of inoculums, potato chips, carrots, grain residues and substrates before cofermentation are shown in Table 1.

The digestate in control bioreactors (R1, R16) has very low organic matter content and serves as an inoculum for providing the anaerobic fermentation process. Generally the anaerobic fermentation process was weak in the inoculums alone, but there are live bacteria community capable to maintain biodegradation of the new portion of the added organic matter. Damaged potato chips (PC) are rich in dry organic matter (95.9\% DOM). Carrots and grain residue (GR) have a high ash content that can be explained by the high content of inorganic impurities in these biomass samples. The samples of grain residue (obtained from feedstock at working biogas plant) have low humidity (87.9\% TS). Average data on gases production from all bioreactors are shown in Table 2. 
Results of analyses of raw material samples before anaerobic digestion

\begin{tabular}{|c|c|c|c|c|c|c|c|c|}
\hline $\begin{array}{c}\text { Bio- } \\
\text { reactors }\end{array}$ & Raw material & Weight, & $\mathbf{p H}$ & $\begin{array}{c}\text { TS } \\
\mathbf{\%}\end{array}$ & $\begin{array}{c}\text { TS } \\
\mathbf{g}\end{array}$ & $\begin{array}{c}\text { ASH } \\
\mathbf{\%}\end{array}$ & $\begin{array}{c}\text { DOM } \\
\mathbf{\%}\end{array}$ & $\begin{array}{c}\text { DOM } \\
\mathbf{g}\end{array}$ \\
\hline R1; R16 & IN & $500 \pm 0.2$ & 7.54 & 3.09 & 15.450 & 27.26 & 72.74 & 11.238 \\
\hline R2-R4 & PC & $10 \pm 0.001$ & & 73.62 & 7.362 & 4.10 & 95.9 & 7.060 \\
\hline R2-R4 & IN + PC & $510 \pm 0.2$ & 7.55 & 4.47 & 22.812 & 19.79 & 80.21 & 18.298 \\
\hline R5-R7 & C & $10 \pm 0.001$ & & 12.19 & 1.219 & 10.52 & 89.48 & 1.091 \\
\hline R5-R7 & IN + C & $510 \pm 0.2$ & 7.56 & 3.27 & 16.669 & 26.04 & 73.96 & 12.329 \\
\hline R8-R10 & GR & $10 \pm 0.001$ & & 87.58 & 8.758 & 9.23 & 90.77 & 7.950 \\
\hline R8-R10 & IN + GR & $510 \pm 0.2$ & 7.54 & 4.75 & 24.208 & 20.74 & 79.26 & 19.188 \\
\hline R11-R15 & 5PC + 5C + 5GR & $15 \pm 0.001$ & & 57.80 & 8.670 & 7.14 & 92.86 & 8.051 \\
\hline R11-R15 & IN + 5PC + 5C + 5GR & $515 \pm 0.2$ & 7.55 & 4.68 & 24.120 & 20.03 & 79.97 & 10.289 \\
\hline
\end{tabular}

Note: IN - inoculum; PC - potato chips; C - carrots; GR - grain residues; ASH - ashes; TS total solids; DOM - dry organic matter (on raw substrate basis); R1-R16-bioreactors.

Table 2

Production of biogas and methane

\begin{tabular}{|c|c|c|c|c|c|c|}
\hline $\begin{array}{c}\text { Bioreac- } \\
\text { tor }\end{array}$ & Raw material & $\begin{array}{c}\text { Biogas, } \\
\quad 1\end{array}$ & $\begin{array}{l}\text { Biogas, } \\
l \cdot g^{-1} \text { DOM }\end{array}$ & $\begin{array}{l}\text { Methane, } \\
\text { aver. \% }\end{array}$ & $\begin{array}{c}\text { Methane, } \\
\text { I }\end{array}$ & $\begin{array}{c}\text { Methane, } \\
\text { l. } \text { - }_{\text {DOM }}\end{array}$ \\
\hline R2 & $\mathrm{IN}+\mathrm{PC}$ & 9.60 & 1.360 & 58.48 & 5.614 & 0.795 \\
\hline R3 & $\mathrm{IN}+\mathrm{PC}$ & 8.20 & 1.161 & 45.38 & 3.721 & 0.527 \\
\hline $\mathrm{R} 4$ & $\mathrm{IN}+\mathrm{PC}$ & 6.40 & 0.907 & 49.75 & 3.184 & 0.451 \\
\hline \multicolumn{2}{|c|}{ Aver. R2-R4 \pm st.dev } & $\begin{array}{l}8.066 \\
\pm 0.80\end{array}$ & $\begin{array}{l}1.143 \\
\pm 0.23\end{array}$ & $\begin{array}{r}51.20 \\
\pm 6.5\end{array}$ & $\begin{array}{r}4.173 \\
\pm 0.1\end{array}$ & $\begin{array}{l}0.591 \\
\pm 0.17\end{array}$ \\
\hline R5 & $\mathrm{IN}+\mathrm{C}$ & 1.10 & 1.007 & 46.08 & 0.464 & 0.425 \\
\hline R6 & $\mathrm{IN}+\mathrm{C}$ & 1.20 & 1.099 & 34.94 & 0.384 & 0.352 \\
\hline R7 & $\mathrm{IN}+\mathrm{C}$ & 1.10 & 1.007 & 38.53 & 0.388 & 0.356 \\
\hline \multicolumn{2}{|c|}{ Aver. R5-R7 \pm st.dev } & $\begin{array}{l}1.103 \\
\pm 0.05\end{array}$ & $\begin{array}{l}1.038 \\
\pm 0.05\end{array}$ & $\begin{array}{l}39.85 \\
\pm \mathbf{5 . 4 3}\end{array}$ & $\begin{array}{l}0.412 \\
\pm 0.04\end{array}$ & $\begin{array}{l}0.378 \\
\pm 0.04\end{array}$ \\
\hline R8 & $\mathrm{IN}+\mathrm{GR}$ & 5.40 & 0.679 & 53.75 & 2.899 & 0.365 \\
\hline R9 & $\mathrm{IN}+\mathrm{GR}$ & 5.50 & 0.692 & 53.18 & 2.926 & 0.368 \\
\hline $\mathrm{R} 10$ & $\mathrm{IN}+\mathrm{GR}$ & 6.30 & 0.792 & 50.00 & 3.151 & 0.396 \\
\hline \multicolumn{2}{|c|}{ Aver. R8-R10 \pm st.dev. } & $\begin{array}{l}5.733 \\
\pm 0.45 \\
\end{array}$ & $\begin{array}{l}0.721 \\
\pm 0.06 \\
\end{array}$ & $\begin{array}{l}52.31 \\
\pm 1.88\end{array}$ & $\begin{array}{l}2.992 \\
\pm 0.13 \\
\end{array}$ & $\begin{array}{l}0.376 \\
\pm 0.02 \\
\end{array}$ \\
\hline R11 & $\mathrm{IN}+\mathrm{PC}+\mathrm{C}+\mathrm{GR}$ & 8.53 & 1.055 & 49.92 & 4.243 & 0.527 \\
\hline R12 & $\mathrm{IN}+\mathrm{PC}+\mathrm{C}+\mathrm{GR}$ & 9.10 & 1.130 & 53.70 & 4.887 & 0.607 \\
\hline R13 & $\mathrm{IN}+\mathrm{PC}+\mathrm{C}+\mathrm{GR}$ & 8.54 & 1.068 & 48.00 & 4.128 & 0.512 \\
\hline R14 & $\mathrm{IN}+\mathrm{PC}+\mathrm{C}+\mathrm{GR}$ & 9.60 & 1.192 & 52.27 & 5.018 & 0.623 \\
\hline $\mathrm{R} 15$ & $\mathrm{IN}+\mathrm{PC}+\mathrm{C}+\mathrm{GR}$ & 6.81 & 0.844 & 44.59 & 3.032 & 0.377 \\
\hline \multicolumn{2}{|c|}{ Aver. R11-R15 \pm st.dev. } & $\begin{array}{l}8.520 \\
\pm 1.40 \\
\end{array}$ & $\begin{array}{l}1.058 \\
\pm 0.12\end{array}$ & $\begin{array}{l}49.70 \\
\pm 4.56 \\
\end{array}$ & $\begin{array}{l}4.262 \\
\pm 0.99 \\
\end{array}$ & $\begin{array}{l}0.529 \\
\pm 0.12 \\
\end{array}$ \\
\hline R16 & IN & 0.10 & 0.009 & 0.50 & 0.0005 & 0.00004 \\
\hline $\mathrm{R} 1$ & IN & 0.20 & 0.018 & 0.50 & 0.001 & 0.00009 \\
\hline
\end{tabular}

Note: $l \cdot g^{-1}{ }_{\text {DOM }}$ - litres per $1 \mathrm{~g}$ dry organic matter added (added fresh biomass into inoculums).

Carrots are a good source of vitamins that facilitates the anaerobic fermentation process.

Average methane content in biogas from potato chips, carrots and grain drying residue samples is shown in Fig. 1. 


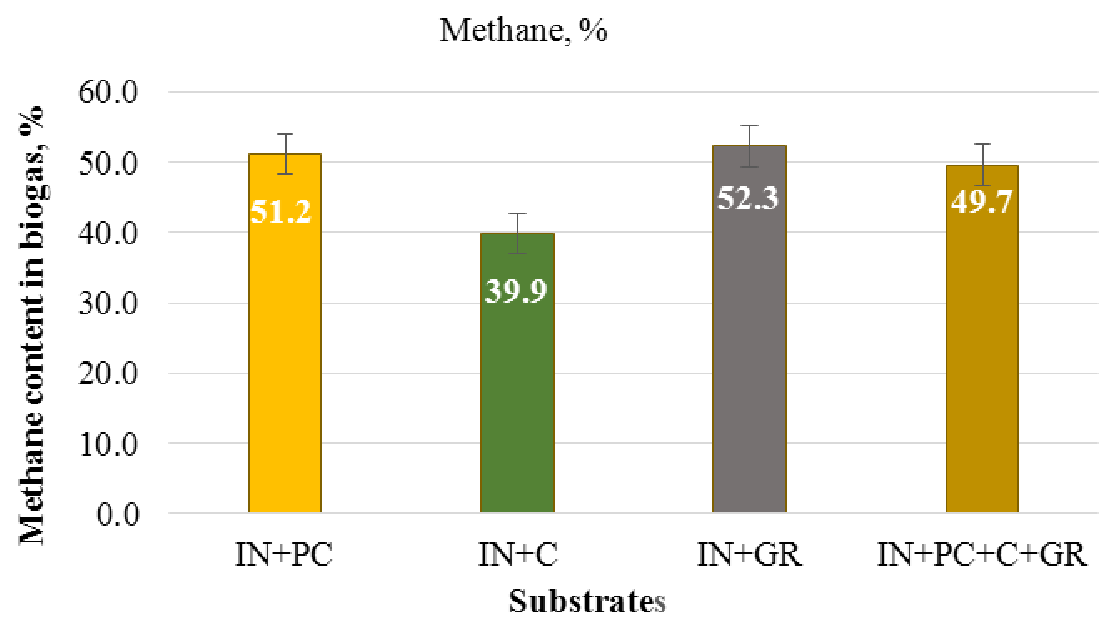

Fig. 1. Average methane content in biogas: $\mathrm{PC}$ - potato chips;

$\mathrm{GR}$ - grain drying residues; $\mathrm{C}$ - carrots

Methane average content in biogas obtained in co-fermentation of carrots, potato chips and grain residues was by $9.8 \%$ higher compared to carrots, and the methane content was lower by $1.5 \%$ or $2.6 \%$ compared to potato chips or grain residues in the mono-fermentation process respectively (Fig. 1). Such slightly lower methane content in biomass mixture can be explained by influence of the low methane content in biogas obtained from carrots. Methane content in biogas increasing can lower carbon dioxide emissions and improve the efficiency of cogeneration engines.

Specific average biogas and methane production yields $\left(1 \cdot \mathrm{g}^{-1}\right.$ DOM $)$ calculated for groups of bioreactors filled with potato chips, carrots and grain residues and processed in mono-fermentation or co-fermentation mode are shown in Fig. 2.

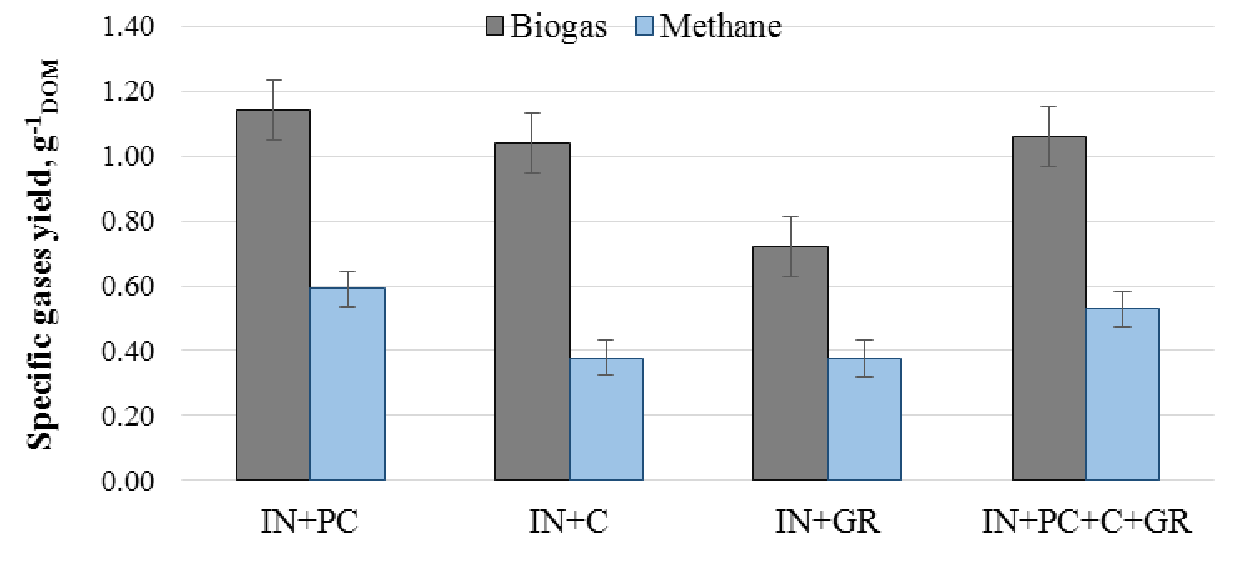

Substrates

Fig. 2. Specific average biogas and methane yield from potato chips, carrots and grain drying residues: $\mathrm{IN}$ - inoculum, $\mathrm{PC}$ - potato chips; $\mathrm{C}$ - carrots; GR -grain drying residues

Biogas and methane production values from reactors R2-R15 (with added biomass), shown in Table 2 and Fig. 2, are provided with already subtracted average values of biogas and methane obtained from the control reactors R1 and R16 (filled with pure inoculums only).

Specific average methane yield from potato chips (R2-R4) substrate in mono-fermentation process was higher by $10.5 \%$ compared to co-fermentation of all biomasses (R11-R15). Specific average methane yield from all biomasses co-fermentation (R11-R15) was higher by $28.6 \%$ or $28.9 \%$ compared to carrots or grain residues, respectively. The best biomass for methane production in mono-fermentation was potato chips and it may also improve the methane yield from cofermentation mixture. Comparison of the obtained results with other researcher's data would not be correct, as the biomass used in this study has original composition and was composed from damaged potato chips, carrots and grain residues in Latvia and was utilized for the first time for the given 
biomass. However, further improvement of methane production can be achieved by implementation of different biomass pre-treatment methods and improvement of the anaerobic conditions.

\section{Conclusions}

1. Average specific methane yield from bioreactors with potato chips was $0.5911 \cdot \mathrm{g}^{-1}$ Dom or by $10.5 \%$ higher compare to that obtained from mixed biomass.

2. Average specific methane yield from bioreactors with carrots was $0.378 \mathrm{l} \cdot \mathrm{g}^{-1}$ DOM.

3. Average specific methane production from bioreactors with grain residues was $0.376 \mathrm{l} \cdot \mathrm{g}^{-1} \mathrm{DOM}$.

4. Average specific methane production from bioreactors with potato chips, carrots and grain residues mixture was $0.529 \mathrm{l} \cdot \mathrm{g}^{-1}$ DOM.

5. Specific methane yield from co-fermentation of potato chips, carrots and grains was higher by $28.6 \%$ or $28.9 \%$ compared to methane produced from mixtures with fermented carrots or grain residues alone, respectively.

6. Increase of the average specific methane production in co-fermentation of biomass is relatively good compared to carrots or grain residues processed in mono-fermentation mode. Further research should focus on findings of more favourable mixtures, based on local biomass supply, substrate $\mathrm{C}: \mathrm{N}$ ratio, anaerobic fermentation conditions and other applicable factors.

\section{Acknowledgements}

This investigation was supported by the Latvian National Research Programme LATENERGI.

\section{LATENERGI}

\section{References}

[1] Atanasiu B. The Role of Bioenergy in the National Renewable Energy Action Plans: A First Identification of Issues and Uncertainties. Publication of the BIOMASS FUTURES project (IEE 08653 SI2. 529 241), 2010, 22 p.

[2] Thrän D., editor. Smart Bioenergy. Springer International Publishing: Switzerland, 2015, 181 p.

[3] Dubrovskis V., Adamovičs A. Bioenergétikas horizonti (Horizons of bioenergetics), Jelgava: Latvia University of Agriculture, 2012, 352 p. (In Latvian).

[4] Kumke G., Langhans G. Plant scale co-fermentation of farm manure and industrial organic wastes. Proceedings: "Fourth International Dairy Bat Housing Conference", 2830.01.1998, St. Louis Missouri, ASAE.

[5] Pakarinen A., Maijala P., Jaakkola S. etc. Evaluation of preservation methods for improving biogas production and enzymatic conversion yields of annual crops. Biotechnol. Biofuels, vol. 4, 2011, 20 p.

[6] Kreuger E., Nges I.A., Björnsson L. Ensiling of crops for biogas production: effects on methane yield and total solids determination. Biotechnol. Biofuels, 2011, vol. 4, 44 p.

[7] Rintala J., Ahring B. Thermophilic anaerobic digestion of source-sorted household solid waste: the effects of enzyme additions. Appl. Microb. \& Biotech., vol. 40, 1994, pp. 916-919.

[8] Warthmann R., Baum S., Baier U. Massnahmen zur Optimierung der Vergärung durch Vorbehandlung, Prozess und Verfahrenstechnol und Hilfsstoffe (Measures for optimizing the fermentation by pretreatment, process and process engineering and auxiliary materials), Bundesamt für Energie BFE, Switzerland, 2012, Project No. 103312 / 154366). (In German).

[9] Gaduš J., Kročko V. Evaluation of co-fermentation under agricultural biogas plant conditions. Motrol, 2006, 8A, pp. 125-132.

[10] Weiland P., Rieger C. Jashresbericht, FAL, Braunschweig, 2000, 341 p. (In German).

[11] Braun R., Wellinger A. Potential of co-digestion,IEA Bioenergy, Tulln, 2003, 16 p.

[12] Dubrovskis V., Plume I. Enzymatic and catalystic enchancement of methane production from corn silage and grain residues.Proceedings of International conference "Engineering for Rural Development",2017, Jelgava, pp. 443-448.

[13] Kaltschmitt M. Methodenhandbuch, 2010, Leipzig. 93 p. (In German). 